\title{
Non-conformity of Goods in Light of the United Nations Convention on Contracts for the International Sale of Goods and the Law on Obligations of the Republic of Macedonia as Part of South-Eastern European Law
}

\author{
Faton Shabani \\ State University of Tetova, Republic of Macedonia \\ faton.shabani@unite.edu.mk
}

Doi:10.5901/ajis.2015.v4n2s1p85

\begin{abstract}
In the practice of sales contracts there are several possible ways in which the seller fails to fulfill his obligations under contract, including: non-delivery or delay in delivery of goods, delivery of non-conforming goods, failure to hand over any documents relating to them and failure in transfer property in the goods. A substantial portion of all sales litigation relates to conformity of goods i.e. in that they do not conform to that which has been agreed. The purpose of this paper is to examine the legal provisions of the United Nations Convention on Contracts for the International Sale of Goods (hereafter CISG) and the Law on Obligations of the Republic of Macedonia (hereafter Law) which regulate the issue of conformity of the goods. Article 35 is the central article of the CISG according to which the goods must conform in the first place to the quantity, quality and description required by the contractual provisions and to be contained or packaged in the manner required by the contract. On the other hand, Article 467 (supplemented by Article 480 and Article 481) of the Law speaks to defects in goods instead of examining issues such a quality, description or packing of the goods. Considering this different approach between two articles the author through the comparative method will aim to highlight the similarities and differences between these two legal instruments in terms of conformity of goods with the contractual agreement.
\end{abstract}

Keywords: conformity of goods, CISG, Law.

\section{Introduction}

In disputes arising from contracts of sale of goods (whether domestic or international), one of the most important issues to meet in practice, is that of conformity, namely non-conformity of goods with the contract. Article 30 of the CISG provides that: "The seller must deliver the goods (...) as required by the contract and this Convention." The determination in this way of that how should be the goods which are delivered, is clearly insufficient, so the CISG in Article 35, goes a step further by detailed compliance standards applied by this Convention. Article 35 is based on a uniform concept of conformity: requiring the seller to deliver goods that will meet contractual requirements (quantity, quality, description and packaging of goods), and establishing requirements in the form of standards which will become mandatory for the seller only as determines this provision "if the parties have agreed otherwise." On the other side, the Law speaks separately to material deficiencies and the quantity of goods. It on Article 467 defines what constitutes a material deficiencies of goods in relation to their features, while deficiencies are grouped into four groups depending on whether it was contracted in connection of the features of goods and whether the seller knew for what purpose the buyer buys goods (Чавдар 2001, 650). In addition, in Articles 480 and 481 is not defined the quantity feature, instead both regulated the situations specifically where provided less or more than the contracted quantity between parties.

\section{Contractual Requirements of Conformity}

\subsection{Quantity}

The quantity of goods delivered by the seller must conform with the contractual requirements. In all instances, the goods are describes using quantitative values. This may occur in a variety of ways; ranging from identifying a single specific good, to listing an exact number, or using broad phrases such as 'entire harvest' (Schwenzer, Hachem, Kee 2012, 374). Any discrepancy in quantity whether more or less than the agreed quantity, consitute a lack of conformity for the purposes of Article 35(1) of the CISG and the buyer must therefore give notice of lack of conformity. Article 35 is based 
on the concept that, in general, discrepancies in quantity constitute a delivery of non conforming goods and not partial non-delivery.

According to provision of Article 480 paragraph 1 of the Law, as partial deficiencies are considered: (a) when only a part of the delivered goods have deficiencies; (b) when is delivered only a part of the goods; (c) when is delivered less than agreed quantity. If the buyer within a reasonable time when received more goods does not state that it rejects, it is thought to have received the excess, and is obliged to pay that by the same price (Article 481(1) of the Law).

Contracts sometimes provide that certain deviations as to quantity are admissible. Where the quantity is only stated as an appromixate amount through clauses such as "more or less", "not less than" or "about" the seller has some latitude as to the amount he can deliver. Morever, in certain sectors, minor discrepancies in quantity are considered to be permissible even without such explicit clauses. Unless the permitted tolerances have been exceeded, such discrepancies do not constitute a non-conformity delivery (Kröll, Mistelis, Viscasillas 2011, 494).

\subsection{Quality}

Apart from the quantity of the goods, the agreement of the parties is also the first reference point for the quality requirements to be met by the goods. The term 'quality', must be understood in a broad way. For the purposes of determining the conformity of the goods under Article 35(1), it is irrelevant whether those circumstances affect the usability or value of the goods due to their nature and durability (Schlechtriem, Schwenzer 2005, 414). In the first place it is naturally encompass the physical features of the goods (Schwenzer, Hachem, Kee 2012, 377). Additionally, quality in the sense of Article 35 also encompasses non-physical attributes of the goods, i.e. factual and legal circumstances affecting the relationship of the goods to their surroundings. Depending on the circumstances of the case, these can include public law regulations, technical standards or compliance with certain standards in production, such a good manufacturing practices or the absence of child labour (Kröll, Mistelis, Viscasillas 2011, 495). The fact that the delivered goods did not come from the agreed country of origin may amount to a defect in quality of the goods (Huber, Mullis 2007, 132).

\subsection{Description}

Article 35(1) also stipulates that any deviation from the contractual description of the goods amounts to a breach of contract. There has been some debate on how to treat the delivery of a so-called "aliud", i.e. of goods which are totally different from the contractual description. The classic examples are taken from sales of specific goods. Examples of this would include cases where the buyer purchases a specific item, for example, a specified painting by Picasso, a specified used machine or the whole load of one particular ship, and the seller does not deliver the chosen item, but another one, i.e. another painting by Picasso, another machine or the load of another vessel. Where the contract is one for the sale of unascertained or generic goods a similar situation arises when the seller delivers a wholly different category of good, for example, if the seller contracts to sell peas and delivers beans (Huber, Mullis 2007, 132-133).

\subsection{Packaging}

In light of the particularities of international transactions, often requiring long distance transportation crossing several borders, packaging may be of the considerable importance. It is naturally within the realm of the principle of freedom of contract that the parties may not only agree in their contract on the features of the goods, but also on the way in which such are to be packaged. Similarly, a contractual obligation regarding the manner of packaging may arise from practices or usages (Schwenzer, Hachem, Kee 2012, 383). The goods will not conform, and there will therefore be a breach, if the goods are not packaged as required by the contract.

\section{Supplemental Standards of Conformity}

\subsection{Fitness for the purpose for which the goods would ordinarily be used}

In the absence of contrary agreement, the goods must be fit for ordinary use. This corresponds to the rule in both instruments: "the goods do not conform with the contract unless they are fit for the purpose for which goods of the same description would ordinarily be used" (Article 35(2)(a) of the CISG); "the deficiencies exist if the goods do not have the 
characteristics necessary for its ordinary use or movement" (Article 467(1) of the Law). As the term "ordinary use" is not defined, the practice suggests that, the goods must be usable under such circumstances as are typical for that kind of goods. In practice, it may be difficult to distinguish between the "ordinary uses" of goods and uses, which, though occurring in practice, may no longer be considered to be ordinary uses. It is impossible to give any generally applicable percentage of how frequent a use must be in practice to qualify as an ordinary use.

\subsection{Fitness for a particular purpose}

Under Article 35(2)(b) of the CISG and Article 467(2) of the Law, the seller is only responsible for the fitness of the goods for a purpose other than the purpose for which they would ordinarily be used, if that purpose has been expressly or impliedly made known to him. There is an infinite number of particular imaginable purposes. Some illustrative examples include a buyer informing the seller that it intends to use the technical equipment under very specific climatic conditions, that squid will be used for long line fishing, or that it is engaged in fair-trading markets. The particular purpose communicated is defeated where the technical equipment cannot withstand the climatic conditions, where the squid is too small to work as bait or too heavy to stay on the hooks, or where the goods are not eligible for fair trading because of inhumane manufacturing processes (Schwenzer, Hachem, Kee 2012, 386). The need for the goods to comply with public law regulations in the state of use may also amount to a particular purpose (Schlechtriem, Schwenzer 2005, 421).

\subsection{Lack of the features expressly or impliedly agreed or stipulated}

According to Article 467(3) of the Law, there is a lack of conformity if the goods do not have the features that expressly or impliedly agreed, i.e. stipulated. Accordingly, it should distinguish the agreed and stipulated features. To agree the features of goods means to enter them into the contract the description of the features of goods, especially those that are peculiar to them. When it comes to individual goods specified in the contract, it should to enter a more detailed description than when it comes to goods by gender. For some goods, it gives a technical description, often accompanied by technical documents and drawings. Stipulated features are those which the goods must have in order to be on the market and could be used. This stipulation usually performed authorities, which can be performed by proper control and usually when such goods are placed on the market (Чавдар 2001, 651).

\subsection{In conformity with sample or model}

As is the position in most domestic sales laws, under the CISG (Article 35(2)(c)) and the Law (Article 467(4)), the seller also warrants that the goods possess the qualities of goods which he has held out as a sample or model. Goods provided as a sample or model, thereby become the agreed standard for the substance of the contract. The parties do not have to contractually agree on a sample or model in order to make it compulsory. The underlying rationale of this standard is that holding out a sample or a model has the same effect as describing the goods in detail. While a sample is taken from the goods to be delivered, a model is supplied to the buyer for his examination where the goods themselves are not available (Schlechtriem, Schwenzer 2005, 423). Moreover, when it comes to selling by sample, the sample is sealed and given to store to both parties or just to the buyer, or to a third person who will determine the parties.

\section{Conclusion}

From a comparative examination of the non-conformity of goods in a sales contract under regulations prescribed by the CISG and the Law, some conclusions emerge. The CISG is clearer and more complete in terms of regulating the nonconformity of goods than the Law. Provisions that regulate the non-conformity are included in one place, specifically in Article 35. It contains contractual requirements agreed by the contracting parties, such as: quantity, quality, description or packaging. On the other hand, the Law is much poor regarding the provisions regulating the non-conformity of goods, they are scattered in several articles (Article 467, 480 and 481) and do not regulate the issue of non-conformity in all, but only the material deficiencies, quantity and the so-called supplement standards of conformity. In this way, as evident absence of the Law assess the lack of involvement of the defining elements for the assessment of non-conformity of goods, such as: quality, description or packaging of the goods. The requirement for supplement standards also known as objective criteria, are largely represented in identically manner on both instruments. 


\section{References}

Huber, Peter, Alastair Mullis. The CISG - a new textbook for students and practitioners. München: Sellier European Law Publishers, 2007.

Kröll, Stefan, Loukas Mistelis, Pilar Perales Viscasillas. UN Convention on Contracts for the International Sale of Goods (CISG): Commentary. München: Verlag C.H. Beck, 2011.

Law on Obligations, Official Gazette of the Republic of Macedonia. No. 18/2001; amended by the Law Amending the Law on Obligations, Official Gazette No.4/2002; No.5/2003; No.84/2008; No.81/2009; No.161/2009; The decision of the Constitutional Court No.121/2001, and No.67/2002.

Schlechtriem, Peter, Ingeborg Schwenzer. Commentary on the UN Convention on the International Sale of Goods (CISG). New York: Oxford University Press, 2005.

Schwenzer, Ingeborg, Pascal Hachem, Christopher Kee. Global Sales and Contract Law. Oxford: Oxford University Press, 2012.

United Nations Convention on Contracts for the International Sale of Goods, Vienna, 11 April 1980.

Чавдар, Кирил. Закон за облигационите односи: коментари, објаснувања, практика и предметен регистар. Скопје: Агенција „АКАДЕМИК“, 2001. 